\title{
PENAMPILAN FENOTIPIK 12 GENOTIP JAGUNG (Zea mays L.) HIBRIDA DI LAHAN KERING
}

\author{
Junyah Leli Isnaini ${ }^{(1)}$, Andi Nur Imran ${ }^{(2)}$, Muhammad Yusuf ${ }^{(3)}$, Usman $^{(4)}$, Nurul \\ Amaliah ${ }^{5)}$ \\ 1,3,5) Jurusan Budidaya Tanaman Perkebunan, Politeknik Pertanian Negeri Pangkep \\ Jl. Poros Makassar Pare-Pare KM 83 Mandalle, Kab. Pangkep \\ ${ }^{2)}$ Fakultas Pertanian, Universitas Islam Maros \\ Jl.Dr.Ratulangi, Turikale, Maros \\ ${ }^{4)}$ Balai Penelitian Tanaman Serealia \\ Jl.Dr.Ratulangi, No.274, Allepolea, Lau Maros \\ Korespondensi:junyahleli_isnaini@yahoo.com
}

\begin{abstract}
ABSTRAK
Perakitan varietas jagung untuk adaptasi lahan kering dibutuhkan calon hibrida yang genotipenya tahan di lahan kering. Genotipe tersebut dapat diketahui dengan penampilan fenotipe yang superior. Penelitian ini bertujuan untuk mengetahui penampilan fenotipik 12 genotip jagung hibrida, dan untuk mengetahui perbandingan penampilan fenotipik masingmasing genotip jagung hibrida di lahan kering. Penelitian disusun mengikuti pola rancangan acak kelompok (RAK) yang terdiri atas 12 perlakuan (8 galur +4 varietas pembanding). Masing-masing diulang tiga kali dan setiap ulangan terdiri atas 4 baris dan masing-masing baris terdapat 25 tanaman, sehingga jumlah unit percobaan sebanyak 300 unit percobaan. Hasil penelitian menunjukkan Genotip ST 201309, ST 201320 merupakan genotipe uji yang secara umum memiliki penampilan fenotipik yang cukup baik disbanding ke empat pembanding. Genotip ST201309, ST 201320, ST 201328, dan ST 201342 merupakan genotip yang memiliki karakter komponen hasil lebih tinggi dari 10 ton.ha ${ }^{-1}$ dan lebih tinggi dari varietas pembanding.
\end{abstract}

Kata Kunci: Jagung Hibrida, Genotip, dan Lahan Kering.

\begin{abstract}
The assembly of maize varieties for dry land adaptation requires hybrid candidates whose genotypes are resistant to dry land. The genotype can be identified by the appearance of a superior phenotype. This research aims to determine the phenotypic appearance of 12 hybrid maize genotypes, and to determine the comparison of the phenotypic appearance of each hybrid maize genotype in dry land. This research was arranged following a randomized block design (RBD) consisting of 12 treatments ( 8 lines +4 control varieties). Each was repeated three times and each replication consisted of 4 rows and each row contained 25 plants, so the number of experiment units was 300 experiment units. The results showed that the genotype ST 201309, ST 201320 was the test genotype which generally had a fairly good phenotypic appearance compared to the four comparators. The genotypes ST201309, ST 201320, ST 201328, and ST 201342 are genotypes that have a higher yield component character than 10 tonnes.ha-1 and higher than the comparison varieties.
\end{abstract}

Keywords: Hybrid Corn, Genotype, and Dry Land. 


\section{PENDAHULUAN}

Kebutuhan akan pangan karbohidrat semakin meningkat akibat pertumbuhan penduduk sulit dipenuhi dengan hanya mengandalkan produksi padi. Tanaman jagung merupakan salah satu komoditas strategis dan bernilai ekonomis serta mempunyai peluang untuk dikembangkan karena kedudukannya sebagai sumber utama karbohidrat dan protein yang kedua setelah beras.

Masalah pangan saat ini masih menjadi prioritas utama dalam kebutuhan masyarakat Indonesia. Permintaan jagung semakin meningkat seiring dengan peningkatan jumlah penduduk dan semakin pesatnya pertumbuhan disektor industri pangan dan makanan ternak. Namun peningkatan permintaan ini tidak diikuti oleh peningkatan produksi jagung, sehingga permintaan-permintaan tersebut kadang tidak terpenuhi. Oleh karena itu, perlu dilakukan pemuliaan tanaman yang bertujuan untuk memaksimalkan potensi genetik tanaman melalui perakitan kultivar unggul baru yang berdaya hasil tinggi berumur genjah, dan berkualitas tinggi serta resisten terhadap kendala biotik dan abiotik. Untuk mendapatkan varietas yang beradaptasi luas perlu dilakukan pengujian di beberapa daerah sentra jagung sehingga pada akhirnya diperoleh suatu varietas yang mempunyai kemampuan adaptasi yang baik terhadap kondisi lingkungan yang berbeda dan produksi tinggi. Semakin tinggi variasi genetik, maka semakin besar peluang pemilihan sifat-sifat yang diinginkan. Heritabilitas merupakan faktor yang mempengaruhi keberhasilan suatu seleksi guna memperbaiki sifat suatu varietas yang menunjukkan hubungan antara genotipe dan fenotipe dari sifat tersebut. Pendugaan nilai heritabilitas berguna untuk mengetahui apakah sifat-sifat tersebut lebih diperankan oleh factor genetik atau faktor lingkungan, sehingga dapat diketahui sejauh mana sifat tersebut dapat diturunkan kepada generasi selanjutnya serta menganalisis seberapa besar interaksi antara genotipe yang diuji terhadap beberapa lingkungan yang berbeda (Balitsereal, 2007).

Budidaya jagung hibrida merupakan salah satu upaya untuk mengatasi permasalahan yang ada, selain produktivitasnya tinggi, umur genjah, ketahanan tanaman juga rendemennya tinggi, varietas hibrida mempunyai adaptasi terhadap jenis tanah dan iklim yang sangat khusus dan hanya akan memberikan hasil optimal bila di tanam pada lingkungan yang sesuai. Untuk mendapatkan varietas yang beradaptasi luas perlu dilakukan pengujian di beberapa daerah sentra jagung sehingga akan diperoleh suatu varietas yang mempunyai kemampuan beradaptasi dan produksi tinggi. Keunggulan keunggulan tersebut diharapkan memberikan keuntungan bagi industri pakan maupun terciptanya swasembada pangan dan akan mampu meningkatkan kesejahteraan petani (Warisno, 2015). Potensi lahan untuk pengembangan jagung tersedia cukup luas, utamanya pada lahan kering di Sulawesi Selatan. Ada sekitar 6,96 juta hektar lahan 
yang terdapat di 14 provinsi tergolong berpotensi untuk pengembangan jagung (Pusat Penelitian dan Pengembangan Tanah dan Agroklimat, 2015).

\section{BAHAN DAN METODE}

Penelitian dilaksanakan pada bulan Februari sampai Juli 2020 dan bertempat di Kebun Percobaan Balitsereal Maros, Kabupaten Maros, Sulawesi Selatan. Menggunakan benih jagung hibrida dengan Genotipe yang diuji (ST201315,ST201328,ST201342, ST201320, ST201359, ST201312, ST201309, ST201319, dan empat pembanding HJ21AGRITAN, Bisi 16, NK212, dan ADV 777 ). Adapun peralatan yang digunakan: timbangan digital dan alat pengukur kadar air (Seed Moisture Tester). Penelitian ini menggunakan percobaan rancangan acak kelompok (RAK) yang terdiri atas 12 perlakuan ( 8 galur +4 varietas pembanding). Masing- masing diulang tiga kali dan setiap ulangan terdiri atas 4 baris dan masing-masing baris terdapat 25 tanaman, sehingga jumlah unit percobaan sebanyak 300 unit percobaan. Model persamaan linier yang digunakan adalah :

Dimana :

$$
\mathrm{Yi}=\mu+\alpha_{\mathrm{i}}+\beta_{\mathrm{j}}+\varepsilon_{\mathrm{ij}}
$$

Yi = hasil pengamatan setiap peubah, $\quad \beta_{\mathrm{j}}=$ pengaruh blok,

$\mu \quad=$ nilai tengah umum,

$\alpha_{\mathrm{i}}=$ pengaruh entri/calon varietas, $\quad \varepsilon_{\mathrm{ij}}=$ pengaruh galat

Dibuat plot dengan ukuran plot $3 \mathrm{~m}$ x 5,0 m , jarak antara plot 0,80 m. Penanaman dilaksanakan dengan menggunakan tugal dengan jarak tanam $0,75 \times 0,20 \mathrm{~m}$ dengan 2 biji perlubang tanam, penjarangan dilakukan saat tanaman berumur 14 hst menjadi satu tanaman per lubang tanam. Pemupukan diberikan 7 hst dan pada saat tanaman berumur 30 hst dengan takaran pupuk sebagai berikut :Pupuk dasar ( 7 hst) : Urea $=200 \mathrm{~kg} / \mathrm{ha}$, Phonska $=300$ $\mathrm{kg} / \mathrm{ha}, \mathrm{ZA}=100 \mathrm{~kg} / \mathrm{ha}$, Pupuk susulan ( $30 \mathrm{hst}$ ): Urea= $200 \mathrm{~kg} / \mathrm{ha}$.

Penyiangan dilakukan 2 - 3 kali tergantung keadaan gulma. Penyiangan pertama pada saat tanaman berumur $2-3$ minggu setelah tanam (mst) dan $4-6$ mst. Penyiangan kedua dapat dilakukan bersamaan dengan pembumbunan. Pembumbunan dilakukan untuk mempermudah pengairan. Pengairan dilakukan setiap 2 minggu sekali, apabila tanahnya dapat menyimpan air pengairan dapat dilakukan setiap 3 minggu sekali. Pengairan sangat mempengaruhi dan harus dilakukan menjelang berbunga dan waktu pengisian biji karena stadia ini akan mempengaruhi hasil panen. Pengendalian hama dan penyakit utama pada tanaman dilakukan untuk mengurangi penurunan hasil dengan menggunakan pestisida atau fungisida sesuai dengan dosis anjuran, untuk pengendalian penyakit bulai benih diberi perlakuan dengan 
metalaksil sebelum ditanam. Pelaksanaan panen dilakukan pada saat tanaman memasuki fase masak fisiologis dengan ditandai terbentuknya black layer pada biji (sekitar umur 95-105 hst).

Pengamatan dilakukan dengan menggunakan parameter sebagai berikut : Umur berbunga ( hari );Pencatatan umur berbunga jantan dihitung saat anthesis atau ketika telah diproduksinya serbuk sari (pollen). Pencatatan umur berbunga betina (silking/keluar rambut) dicatat bila rambut telah keluar panjang $\pm 2 \mathrm{~cm}$. Tinggi Tanaman ( $\mathrm{cm}$ ) ;Pengukuran tinggi tanaman dilakukan menjelang panen. Dipilih 5-10 tanaman secara acak di setiap petakan. mengukur jarak dari dasar tanaman di permukaan tanah sampai pangkal terakhir bunga jantan. Tinggi Letak Tongkol ( cm );Dilakukan sekaligus/bersamaan dengan pengukuran tinggi tanaman terhadap 5 - 10 sampel diatas. Mengukur jarak dari permukaan tanah sampai dasar kedudukan tongkol. Bila tanaman mempunyai dua tongkol, maka diambil tongkol yang teratas/tongkol yang lebih normal perkembangannya. Menutupnya Kelobot ( husk cover ); Tingkat penutupan kelobot diamati dengan memberi skor 1 (baik ) sampai 5 (jelek), pedoman penilaian/sekor disajikan pada gambar 1 dengan kriteria sebagai berikut : Skor 1 : kelobot menutup rapat dengan baik, sehingga beberapa tongkol dapat diikat menjadi satu pada ujung tongkol. Skor 2 : Kelobot menutup ketat hanya sampai ujung tongkol saja. Skor 3 : Kelobot menutup agar longgar di ujung tongkol. Skor 4: Kelobot menutup tongkol urang baik, ujung tongkol terlihat. Skor 5 : Kelobot menutup tongkol sangat jelek, sebahagian biji Nampak tidak dilindungi kelobot. Bobot Tongkol Kupasan; Tongkol-tongkol yang dipanen, setelah dikupas ditimbang beratnya per petak. Kadar Air Panen; Setelah ditimbang bobot kupasan tongkol diambil 5 - 10 tongkol sampel per petak lalu setiap tongkol dipipil bijinya 3 baris. Biji yang dipipil dimasukkan secara bersama-sama dan ukur kadar air dengan alat ukur ( Seed Moisture Tester ). Komponen Hasil; Data ukuran komponen hasil diambil dari sejumlah tongkol sampel yang telah dikeringkan.

\section{Konversi Hasil per petak ke Kg/ha.}

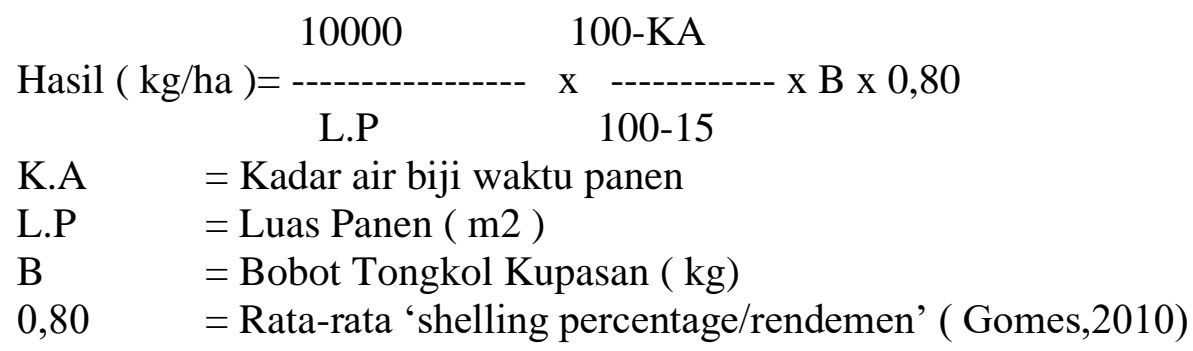




\section{HASIL DAN PEMBAHASAN}

Delapan genotipe uji dan empat varietas pembanding yang diamati secara umum menunjukkan pertumbuhan yang cukup baik, sidik ragam terdapat dua peubah yang berbeda nyata yaitu panjang tongkol, dan diameter tongkol, sembilan peubah berbeda sangat nyata yaitu peubah umur berbunga jantan, umur berbunga betina, bobot tongkol kupasan basah, jumlah baris, jumlah biji, tinggi tanaman, tinggi letak tongkol, bobot 1000 biji dan hasil, sedangkan dua peubah lainya berpengaruh tidak nyata yakni husk cover (penutupan klobot), kadar air (Tabel $1)$.

Nilai koefisien keragaman dari semua peubah yang diamati terdapat satu peubah yang nilainya lebih besar dari 20\% yakni peubah husk cover (pentupan kelobot). Hal ini menunjukkan bahwa keragaman yang ditimbulkan oleh karena kesalahan atau faktor yang tidak bisa dikendalikan kecil. Dengan demikian derajat ketelitian hasil penelitian cukup tinggi.

Menurut Sastrosupadi (1999), koefisien keragaman merupakan ukuran keragaman relatif data yang diperoleh dari suatu percobaan yang dinyatakan dalam $(\%)$.

Tabel 1. Nilai F hitung 8 genotip uji dan 4 Pembanding di KP Maros, MK2017.

\begin{tabular}{llc}
\hline Peubah & F. Hitung & KK \% \\
\hline Umur berbunga jantan & $20.44^{* *}$ & 1.2 \\
Umur berbunga betina & $27.48^{* *}$ & 1.2 \\
Skor penutupan klobot & $1.18^{\text {tn }}$ & 26.9 \\
Bobot kupasan basah & $8.07^{* *}$ & 6.3 \\
Kadar air & $0.87^{\text {tn }}$ & 7.3 \\
Panjang tongkol & $2.52^{*}$ & 7.9 \\
Diameter Tongkol & $3.02^{*}$ & 13.7 \\
Jumlah baris & $19.92^{* *}$ & 5.0 \\
Jumlah biji & $7.62^{* *}$ & 5.0 \\
Tinggi tanaman & $12.82^{* *}$ & 2.9 \\
Tinggi tongkol & $18.06^{* *}$ & 4.1 \\
Bobot 1000 biji & $12.13^{* *}$ & 3.8 \\
Hasil & $4.84^{* *}$ & 8.5 \\
\hline
\end{tabular}

Keterangan : tn $=$ berpengaruh tidak nyata; $*$ berpengaruh nyata: ** berpengaruh sangat nyata.

\section{a. Umur berbunga jantan}

Pengamatan umur berbunga jantan dan umur berbunga betina disajikan pada Tabel 2 . Hasil pengamatan 8 genotip pada umur berbunga jantan terdapat dua genotipe yang umurnya lebih pendek dari varietas pembanding HJ 21 Agritan, Bisi 16, NK 212. Hasil pengamatan untuk umur berbunga betina pada Tabel 3 terdapat 3 genotipe yang umur 
berbunga betinanya lebih pendek dari varietas pembanding HJ 21 Agritan, Bisi 16, dan NK 212. Genotip ST 201309 memiliki rerata umur berbunga jantan dan umur berbunga betina paling genjah (50,1 hst dan 53,0 hst). Semakin cepat umur berbunga maka umur panen juga akan lebih genjah (Wibowo 2010).

\section{b. Tinggi tanaman dan Tinggi letak tongkol}

Hasil pengukuran tinggi tanaman dan tinggi letak tongkol disajikan pada Tabel 2, genotype yang tertinggi adalah genotip ST201364 tingginya mencapai $233.8 \mathrm{~cm}$ dan terendah adalah genotip ST201342 tingginya $202.5 \mathrm{~cm}$ dan berpengaruh sangat nyata pada taraf uji LSD 5\%. tanaman terendah terdapat pada genotip ST $201342(202.5 \mathrm{~cm})$. sifat tanaman yang diinginkan adalah tidak terlalu tinggi dan memiliki batang yang kuat untuk mengurangi kerebahan yang dapat berpengaruh terhadap produksi. Menurut Murdolelono et al. (2011) penampilan varietas jagung yang baik adalah tanamannya pendek tetapi kekar batangnya sehingga tahan terhadap kerebahan. Genotipe yang memiliki karakter tinggi letak tongkol tertinggi yaitu ST201328 dengan tinggi mencapai $128.1 \mathrm{~cm}$ dan genotip yang terendah yaitu ST201364 tingginya $108.5 \mathrm{~cm}$ dan berpengaruh sangat nyata pada taraf uji LSD 5\%. menurut Hamida (2011) bahwa letak tongkol terbaik berada di pertengahan batang sehingga menyebabkan tanaman tahan rebah. Namun menurut Amir dan Najmah (2011) bahwa letak tongkol yang tinggi dapat mencegah serangan hama.

\section{c. Skor penutupan klobot (HC)}

Pengamatan parameter penutupan kelobot pada Tabel 2 menunjukan bahwa skor penutupan kelobot terbaik yaitu genotip ST201312, ST201315, dan ST201328 dengan skor penutupan kelobot yaitu 1.7 dan skor penutupan kelobot terendah yaitu ST201309 dan ST201364 dengan skoring 2,7. Skor 1,7 berarti klobot menutup dngan baik. Berdasarkan uji LSD 5\% skor penutupan klobot berbeda tidak nyata dengan keempat varietas pembanding. Kelobot yang menutup rapat dapat mengurangi intensitas air yang meresap ke dalam tongkol sehingga dapat mencegah pertumbuhan jamur. Kelobot yang menutup baik dan rapat dapat melindungi tongkol dan biji dari serangan hama Sitophillus zeamais Motsh (Demissie et al. 2008).

\section{d. Panjang tongkol dan diameter tongkol}

Hasil pengukuran panjang tongkol dan diameter tongkol disajikan pada Tabel 3, genotipe yang memiliki panjang tongkol yang terpanjang yaitu genotip ST201309, sedangkan genotip yang tependek yaitu genotip ST201342. Genotipe yang memiliki diameter tongkol terbesar yaitu ST201328, sedangkan untuk genotip yang memiliki diameter terkecil yaitu genotip ST201312. Berdasarkan uji LSD 5\% Panjang tongkol dan 
diameter tongkol berbeda nyata dengan keempat varietas pembanding. Panjang tongkol dan diameter tongkol berpengaruh pada jumlah baris biji. Semakin Panjang dan besar diameter tongkolnya, maka peluang untuk mendapatkan hasil biji yang tinggi lebih besar. Namun jumlah biji sangat ditentukan oleh berhasilnya persilangan antara jantan dan betina dan ini dipengaruhi oleh faktor genetic dan lingkungan. Pradnyawathi (2012) melaporkan bahwa peranan gen lebih dominan terhadap jumlah biji. Hasil dari fotosintesis akan diakumulasikan untuk pembentukan dan pengisian biji (Bustaman 2004, Dewi et al. 2014).

Tabel 2. Nilai tengah untuk umur berbunga jantan, umur berbunga betina tinggi tanaman, tinggi tongkol penutupan klobot dan uji pembanding.

\begin{tabular}{lccccc}
\hline \multirow{2}{*}{ Hibrida } & \multicolumn{2}{c}{ Umur Berbunga } & Tinggi & Tinggi & HC \\
\cline { 2 - 3 } & Jantan 50\% & Betina 50\% & Tanaman & Tongkol & H. \\
\hline ST 201309 & $51.0^{\mathrm{d}}$ & $53.0^{\mathrm{d}}$ & 228.1 & 125.6 & 2.7 \\
ST 201312 & 55.3 & 58.0 & 218.0 & 114.5 & 1.7 \\
ST 201315 & 55.3 & 59.0 & 222.2 & 120.4 & 1.7 \\
ST 201320 & $51.3^{\mathrm{d}}$ & $53.3^{\mathrm{d}}$ & 225.7 & 113.1 & 2.3 \\
ST 201328 & 54.3 & $56.0^{\mathrm{a}}$ & 223.3 & 128.1 & 1.7 \\
ST 201342 & $51.7^{\text {bd }}$ & $53.7^{\mathrm{d}}$ & 202.5 & 115.3 & 2.0 \\
ST 201359 & $54.0^{\mathrm{a}}$ & $56.0^{\mathrm{a}}$ & 213.0 & 123.1 & 2.0 \\
ST 201364 & $52.3^{\mathrm{b}}$ & $55.0^{\mathrm{c}}$ & 233.8 & 108.5 & 2.7 \\
\hline HJ 21 Agritan (a) & 53.7 & 55.7 & 219.8 & 110.6 & 2.3 \\
Bisi 16 (b) & 51.7 & 54.0 & 236.5 & 129.2 & 2.0 \\
NK 212 (c) & 52.7 & 54.7 & 223.8 & 120.5 & 2.3 \\
ADV 777 (d) & 51.0 & 53.0 & 188.9 & 85.9 & 2.3 \\
\hline LSD 0.05 & 1.0 & 1.1 & 10.8 & 8.1 & 1.0 \\
\hline
\end{tabular}

Keterangan: $\mathrm{a}=$ nyata lebih tinggi dari $\mathrm{HJ} 21$ Agritan $3, \mathrm{~b}=$ nyata lebih tinggi dari Bisi $16, \mathrm{c}=$ nyata tinggi dari NK 212, $d=$ nyata lebih tinggi dari ADV777, pada taraf uji LSD $5 \%$.

\section{e. Jumlah baris, Jumlah biji, dan bobot 1000 biji}

Penghitungan jumlah baris, jumlah biji, dan bobot 1000 biji disajikan pada Tabel 4, terdapat 3 genotip yang jumlah baris biji dan jumlah bijinya lebih banyak dibanding ke empat pembanding. Bobot 1000 biji tertinggi yaitu genotip ST201364 dengan berat 412.3. Hal ini menunjukkan bahwa bobot 1000 biji lebih besar daripada varietas pembanding NK 212 dan ADV 777. Jumlah baris dan jumlah biji serta bobot 1000 biji sangat mempengaruhi hasil biji (produksi). 
Tabel 3. Nilai tengah panjang tongkol, diameter tongkol, jumlah baris, jumlah biji, dan bobot 1000 biji genotip uji serta varietas pembanding.

\begin{tabular}{lcclcc}
\hline \multicolumn{1}{c}{ Hibrida } & $\begin{array}{c}\text { Panjang } \\
\text { tongkol (cm) }\end{array}$ & $\begin{array}{c}\text { Diameter tongkol } \\
\text { (cm) }\end{array}$ & $\begin{array}{c}\text { Jumlah } \\
\text { baris }\end{array}$ & $\begin{array}{c}\text { Jumlah } \\
\text { biji }\end{array}$ & $\begin{array}{c}\text { Bobot 1000 } \\
\text { biji }\end{array}$ \\
\hline ST 201309 & 193.3 & 42.5 & $13.5^{\text {a }}$ & 38.4 & 410.0 \\
ST 201312 & 162.7 & 29.1 & $12.7^{\text {bd }}$ & 32.4 & 343.7 \\
ST 201315 & 188.5 & 42.9 & $14.4^{\text {a }}$ & $36.0^{\text {cd }}$ & 335.2 \\
ST 201320 & 182.7 & 44.0 & $13.6^{\text {a }}$ & 38.0 & 381.8 \\
ST 201328 & 158.9 & 45.7 & $14.4^{\text {a }}$ & 36.1 & 365.6 \\
ST 201342 & 157.3 & 38.9 & $12.4^{\text {bd }}$ & 30.4 & 397.2 \\
ST 201359 & 173.2 & 33.7 & 11.6 & 33.5 & 410.5 \\
ST 201364 & 166.1 & 34.5 & 11.5 & 29.8 & 412.3 \\
\hline HJ 21 Agritan (a) & 177.7 & 45.6 & 13.5 & 34.7 & 431.1 \\
Bisi 16 (b) & 171.3 & 40.9 & 12.1 & 36.5 & 414.3 \\
NK 212 (c) & 179.1 & 46.7 & 14.5 & 36.0 & 370.0 \\
ADV 777 (d) & 194.3 & 44.2 & 13.1 & 36.0 & 395.1 \\
\hline LSD 0.05 & 0.6 & 23.6 & 0.7 & 2.9 & 25.2 \\
\hline
\end{tabular}

Keterangan: a = nyata lebih tinggi dari HJ21 Agritan 3, b = nyata lebih tinggi dari Bisi $16, \mathrm{c}=$ nyata tinggi dari NK212 2, $d$ = nyata lebih tinggi dari ADV777 pada taraf uji LSD $5 \%$

\section{f. Bobot kupasan basah, kadar air, dan Produksi}

Hasil pengukuran bobot tongkol panen, kadar air, dan produksi disajikan pada Tabel 4, terdapat 3 genotip yang lebih berat bobot tongkol kupasannya dibandingkan dengan varietas pembanding HJ 21 AGritan, dan Bisi 16. Terdapat dua genotype uji yang KA panennya lebih rendah dibanding ke empat pembanding. Berat bobot tongkol kupasan dipengaruhi oleh Panjang tongkol, diameter tongkol, dan KA air biji saat panen. Terdapat tiga genotype yang memiliki produksi tertinggi dibanding pembanding HJ 21 AGritan, Bisi 16, dan ADV 777. Ini menunjukkan bahwa genotype uji meupakan genotype calon hibrida yang berpeluang untuk dijadikan varietas hibrida. Genotip jagung hibrida memiliki potensi hasil yang lebih tinggi daripada varietas bersari bebas karena adanya efek hybrid vigor atau heterosis (Takdir et al., 2007).

Pada Tabel 4 terdapat empat genotipe yang memiliki produksi cukup tinggi yaitu ST201309, ST201320, ST201328, dan ST201342 dengan rerata produksi diatas $10 \mathrm{t} / \mathrm{ha}$. hal ini disebabkan keempat genotip tersebut mimiliki karakter komponen produksi dan karakter produksi relative lebih tinggi daripada genotip lainnya. Program pemuliaan tanaman umumnya bertujuan untuk meningkatkan produktivitas tanaman dalam merakit suatu kultivar (Carsono, 2008). Lebih lanjut Mangoendidjojo (20013) mengatakan bahwa pemuliaan tanaman bertujuan untuk mendapatkan varietas unggul yang mempunyai kemampuan berproduksi yang tinggi. Varietas unggul diperlukan sebagai pengembangan 
tanaman secara intensif yang bertujuan untuk meningkatkan hasil produksi persatuan lahan.

Sehingga diharapkan dapat berpotensi menguntungkan dari segi ekonomi.

Tabel 4. Rerata parameter bobot kupasan basah, jumlah tanaman panen, jumlah tongkol panen, kadar biji, dan hasil genotip uji serta varietas pembanding.

\begin{tabular}{lccl}
\hline \multicolumn{1}{c}{ Hibrida } & $\begin{array}{c}\text { bobot kupas basah } \\
(\mathbf{k g})\end{array}$ & Kadar air \% & Produksi (t/ha) \\
\hline ST 201309 & $11.9^{\mathrm{ab}}$ & 26.6 & $11.3^{\mathrm{ab}}$ \\
ST 201312 & 9.8 & 27.3 & 9.5 \\
ST 201315 & 9.8 & 28.2 & 9.1 \\
ST 201320 & $11.8^{\mathrm{ab}}$ & 28.1 & $11.3^{\mathrm{ab}}$ \\
ST 201328 & $12.1^{\mathrm{ab}}$ & 26.2 & $11.5^{\mathrm{ab}}$ \\
ST 201342 & $10.6^{\mathrm{d}}$ & 25.2 & 10.3 \\
ST 201359 & $10.7^{\mathrm{d}}$ & 28.1 & 9.8 \\
ST 201364 & 8.7 & 25.3 & 8.4 \\
\hline HJ21 Agritan (a) & 11.3 & 27.5 & 11.1 \\
Bisi 16 (b) & 11.6 & 26.9 & 11.1 \\
NK 212 (c) & 12.3 & 26.0 & 12.2 \\
ADV 777 (d) & 10.0 & 26.3 & 10.0 \\
\hline LSD 0.05 & 1.2 & 3.3 & 1.5 \\
\hline
\end{tabular}

Keterangan : $\mathrm{a}=$ nyata lebih tinggi dari HJ21 Agritan 3, b = nyata lebih tinggi dari NK212, $\mathrm{c}=$ nyata tinggi dari Bisi 16, $d=$ nyata lebih tinggi dari ADV777 pada taraf uji LSD $5 \%$

\section{KESIMPULAN}

1. Genotip ST 201309, ST 201320 merupakan genotipe yang secara umum memiliki penampilan fenotipik yang cukup baik dibanding ke empat pembanding.

2. Genotip ST201309, ST 201320, ST 201328, dan ST 201342 merupakan genotip yang memiliki karakter komponen hasil lebih tinggi dari 10 ton ha $^{-1}$ dan lebih tinggi dari varietas pembanding.

\section{UCAPAN TERIMA KASIH}

Disampaikan terima kasih dan penghargaan kepada Direktorat Jenderal Pendidikan Vokasi, Kementerian Pendidikan dan Kebudayaan (Kemendikbud) yang telah mendanai penelitian ini.

\section{DAFTAR PUSTAKA}

Amir dan S.T. Najmah. 2011. Uji adaptasi beberapa varietas jagung pada lahan sawah tadah hujan di Takalar. Dalam: Seminar Nasional Serealia. Balai Penelitian Tanaman Serealia, Maros. P. 44-48. 
Aqil, M., Fadhly A.F., \& Zubachtirodin. 2012. Highlight Balai Penelitian Tanaman Serealia. Maros. Badan Penelitian Dan Pengembangan Pertanian Pusat Penelitian Dan Pengembangan Tanaman Pangan Balai Penelitian Tanaman Serealia.

Azrai, M. 2008. Pemanfaatan Markah Molekular dalam Proses Seleksi Pemuliaan Tanaman. J. Agrobiogen. Vol. 11(1):26-37.

Badan Pusat Statistik. 2015. Sulawesi Selatan dalam Angka. Badan Pusat Statistik Provinsi Sulawesi Selatan. Makassar.

Balitsereal (Balai Penelitian Tanaman Serealia). 2007. Jagung Hibrida Unggul Nasional. Maros. Sinar Tani.

Balitsereal, 2010. Deskripsi Varietas Unggul Jagung ,Edisi ke-4, Badan Litbang Pertanian, Balitsereal.

BMKG, 2014. Balai Besar Meteorologi Klimatologi Dan Geofisika Wilayah IV Makassar. Stasiun Klimatologi Kelas 1 Maros. Maros-Sulawesi Selatan.

Budiman, H. 2014. Sukses Bertanam Jagung Komuditas Pertanian Yang Menyajikan. Solo. Penerbit Pustaka Baru Press.

Bustaman, T., 2004. Pengaruh posisi daun jagung pada batang terhadap pengisian dan mutu benih. Stigma 12(2):205-208.

Carsono, N. 2008. Peran Pemuliaan Tanaman dalam Meningkatkan ProduksiPertanian di Indonesia. Abstrak.

Chafid, Muhammad, 2015. Outlook Komoditas Tanaman Pertanian Jagung, Pusat Data dan Sistem Informasi Pertanian,Kementerian Pertanian Jakarta.

Demissie, G.T. Tefera, and A. Tadesse. 2008. Importance of husk covering on field infestation of maize by Sitophillus zeamays Motsch (Coleoptera: Curculionidea) at Bako, Western Ethiopia. African Journal of Biotechnology 7(20):3777-3782.

Dinas Pertanian Tanaman Pangan dan Hortikultura Provinsi Sulawesi Selatan 2015. Program Serealia Sulawesi Selatan. Pemerintah Provinsi Sulawesi Selatan.

Gomes Kwanchai A dan Gomes Arturo , 2010. Prosedur Statistik untuk Penelitian Pertanian, UI Press Jakarta

Hamida, D.N. 2011. Peranan karakter komponen produksi terhadap produksi jagung dalam upaya memperoleh karakter penyeleksi: Skripsi. Universitas Jember. Jawa Timur.

Herniwati \& Tandisau, P. 2009. Keragaan Jagung Varietas Sukmaraga Sebagai Benih Sumber Di Kabupaten Luwu Utara. Balai Pengkajian Teknologi Pertanian Sulawesi Selatan.

Iriany, R.N., Yasin M.H.G., \& Takdir A.M. 2007. Asal, Sejarah, Evolusi, dan Taksonomi Tanaman Jagung. Maros. Balai Penelitian Tanaman Serealia. 
Iwayan Sudika, 2014. Varietas Unggul Jagung untuk Lahan Kering, LP2M Universitas Mataram.

Kasim, F., Subandi, Wakman, W., Prastowo, B., Saenong, S., \& Fadhly, A.F. 1998. Prosiding Seminar dan Lokakarya Nasional Jagung. Maros. Balai Penelitian Tanaman Serealia.

Mangoendidjojo, W. 2003. Dasar-Dasar Pemuliaan Tanaman. Kanisius. Yogyakarta.

Mangoendidjojo, W. 2007. Analisis Interaksi Genotip dengan Lingkungan Tanaman The. J.Zuriat. 11 (1): 15-21.

Marwah, Sitti. 2001. Daerah Aliran Sungai (DAS) Sebagai Satuan Unit Perencanaan Pembangunan Pertanian Lahan Kering Berkelanjutan.. Makalah Falsafah Sains. Program Pasca Sarjana/S3. IPB.

Maintang dan M. Nurdin. 2013. Pengaruh waktu penyerbukan terhadap keberhasilan pembuahan jagung pada populasi SATP-2(S2)C6. Jurnal Agribisnis Kepulauan 2(2):94-108.

Mewa Ariani, 2015. Memperkuat Kemampuan Swasembada Pangan, IAARD Press Jakarta

Murdolelono, B., H.D. Silva, dan M. Azrai. 2011. Uji galur/varietas jagung hibrida umur genjah. Dalam: Seminar Nasional Serealia. Balai Penelitian Tanaman Serealia, Maros. p. 49-56.

Pradnyawathi, N.L.M. 2012. Evaluasi galur jagung smb-5 hasil seleksi massa varietas local Bali "Berte" pada daerah kering. Jurnal Bumi Lestari 12(1):106-115.

Purwanto, S. 2007.Perkembangan Produksi dan Kebijakan dalam Peningkatan Produksi Jagung. Maros. Balai Penelitian Tanaman Serealia. Direktorat Budi Daya Serealia \& Direktorat Jenderal Tanaman Pangan.

Pusat Penelitian dan Pengembangan Tanah dan Agroklimat 2015. Peta Potensi Lahan Pengembangan Jagung di Indonesia.

Sembiring, S. 2007. Studi Karakteristik Beberapa Varietas Jagung Hasil Three Way Cross. Skripsi. Universitas Sumatera Utara. Medan.

Suarni \& Widowati, S. 2007. Struktur, Komposisi, dan Nutrisi Jagung. Maros. Balai Penelitian Tanaman Serealia.

Subandi, I.G., Ismail, dan Hermanto. 1998. Teknologi Produksi dan Pascapanen Jagun. Bogor. Pusat Penelitian dan Pengembangan Tanaman Pangan.

Subekti, N.A. Syafruddin, Efendi, R. dan Sunarti, S. 2007. Morfologi Tanaman Dan Fase Pertumbuhan Jagung. Balai Penelitian Tanaman Serealia. Maros.

Syafruddin, Faesal, \& Akil, M. 2007. Pengelolaan Hara pada Tanaman Jagung. Maros. Balai Penelitian Tanaman Serealia.

Takdir, A.M., R. Neni Iriany., dan M.J. Mejaya. 2007. Adaptasi genotip calon hibrida jagung di beberapa lokasi. Penelitian Pertanian Tanaman Pangan 26(1):20-25.

Warisno, 2015. Seri Budidaya Jagung Hibrida. Penerbit Kanisus Jakarta 
Yasin Muhammad, 2010. Karakteristik Isolat- Isolat Beauveria spp. (Moniliales : Moniliaceae) dan Virulensinya Pada Hama Penggerak Batang Jagung ostrinia furnacalis guenee (Lepidoptera : Pyralidae) Disertasi Program Pasca Sarjana Universitas Hasanuddin

Yatim, W.2010. Genetika. Edisi ke-5. Penerbit Tarsito Bandung. 